\title{
Reservoir characterization of the Upper Jurassic geothermal target formations (Molasse Basin, Germany): role of thermofacies as exploration tool
}

\author{
S. Homuth ${ }^{1}$, A. E. Götz ${ }^{2}$, and I. Sass ${ }^{3}$ \\ ${ }^{1}$ Züblin Spezialtiefbau GmbH, Ground Engineering, Europa Allee 50, 60327 Frankfurt a. M., Germany \\ ${ }^{2}$ University of Pretoria, Department of Geology, Private Bag X20, Hatfield, 0028 Pretoria, South Africa \\ ${ }^{3}$ Technische Universität Darmstadt, Geothermal Science and Technology, Schnittspahnstraße 9, 64287 \\ Darmstadt, Germany
}

Correspondence to: S. Homuth (sebastian.homuth@zueblin.de)

Received: 16 June 2014 - Revised: 8 May 2015 - Accepted: 6 June 2015 - Published: 22 June 2015

\begin{abstract}
The Upper Jurassic carbonates of the southern German Molasse Basin are the target of numerous geothermal combined heat and power production projects since the year 2000. A production-orientated reservoir characterization is therefore of high economic interest. Outcrop analogue studies enable reservoir property prediction by determination and correlation of lithofacies-related thermo- and petrophysical parameters. A thermofacies classification of the carbonate formations serves to identify heterogeneities and production zones. The hydraulic conductivity is mainly controlled by tectonic structures and karstification, whilst the type and grade of karstification is facies related. The rock permeability has only a minor effect on the reservoir's sustainability. Physical parameters determined on oven-dried samples have to be corrected, applying reservoir transfer models to water-saturated reservoir conditions. To validate these calculated parameters, a Thermo-Triaxial-Cell simulating the temperature and pressure conditions of the reservoir is used and calorimetric and thermal conductivity measurements under elevated temperature conditions are performed. Additionally, core and cutting material from a $1600 \mathrm{~m}$ deep research drilling and a $4850 \mathrm{~m}$ (total vertical depth, measured depth: $6020 \mathrm{~m}$ ) deep well is used to validate the reservoir property predictions. Under reservoir conditions a decrease in permeability of 2-3 magnitudes is observed due to the thermal expansion of the rock matrix. For tight carbonates the matrix permeability is temperature-controlled; the thermophysical matrix parameters are density-controlled. Density increases typically with depth and especially with higher dolomite content. Therefore, thermal conductivity increases; however the dominant factor temperature also decreases the thermal conductivity. Specific heat capacity typically increases with increasing depth and temperature. The lithofacies-related characterization and prediction of reservoir properties based on outcrop and drilling data demonstrates that this approach is a powerful tool for exploration and operation of geothermal reservoirs.
\end{abstract}

1

\section{Introduction}

To assess the potential and productivity of a hydrothermal or petrothermal reservoir, detailed knowledge of the thermoand petrophysical as well as mechanical rock and formation properties is mandatory. In general, the determination of these reservoir properties is limited to costly and timeconsuming exploration drillings, which give only a limited insight into the entire reservoir system. Especially in terms of carbonates it is difficult to evaluate the heterogeneity of different facies zones in seismic sections (Chilingarian et al., 1992), which applies to the Upper Jurassic (Malm) target formation of numerous planned geothermal power plant projects in the southern German Molasse Basin. These carbonates are characterized by a karst-fractured aquifer system (Schulz et al., 2012) located 3500-5500 m below the surface in the southern part of the Molasse Basin. This basin represents a typical example of a conduction-dominated geother- 


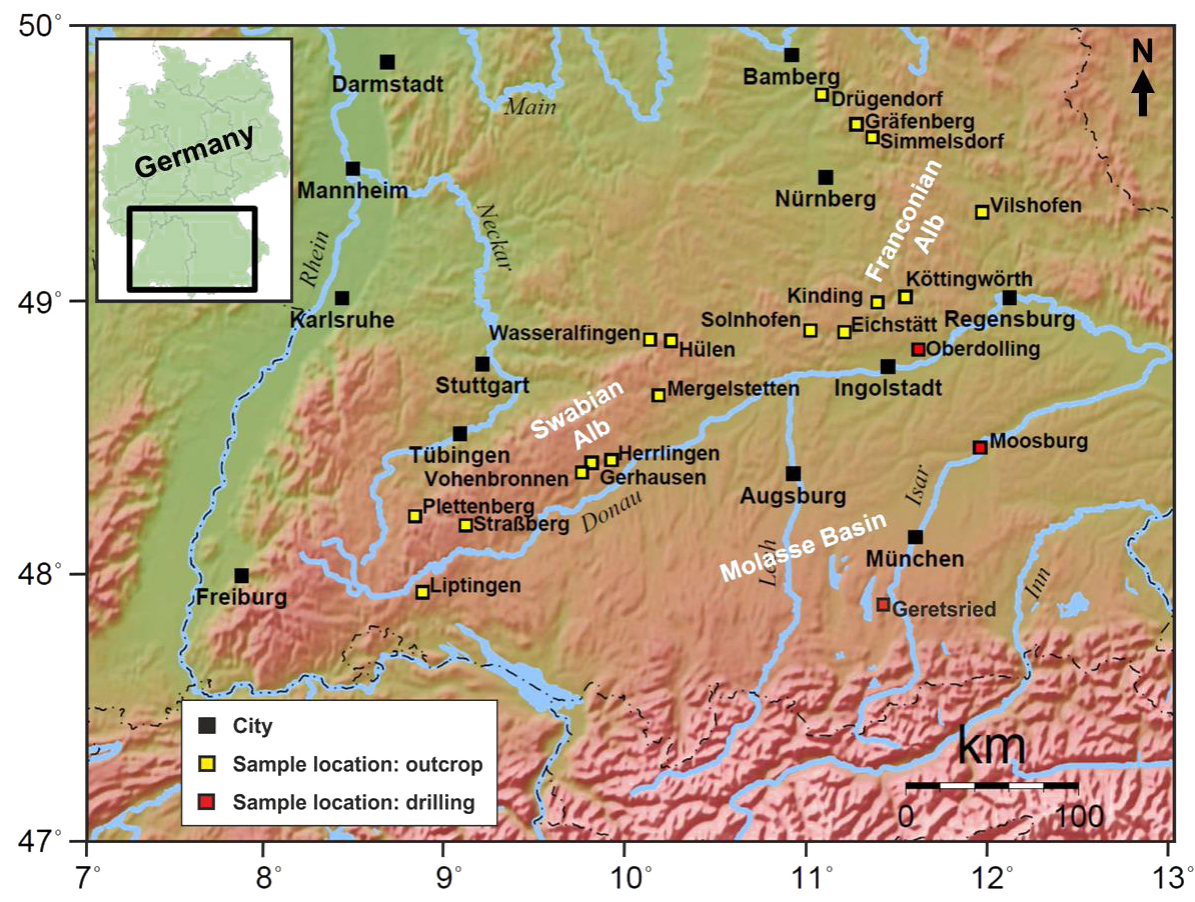

Figure 1. Investigated outcrop analogues in the Swabian and Franconian Alb north of the Molasse Basin, southern Germany.

mal play type where the sedimentary sequences of the foreland basin (Molasse Basin) are influenced by significant crustal subsidence towards the orogenic belt (Alps) due to the weight of the thickened crust of the orogenic belt and loading of erosional products from the mountain belt on the non-thickened crust (Moeck and Beardsmore, 2014).

Outcrop analogue studies enable the determination and correlation of thermo- and petrophysical parameters as well as structural geology data with regional facies patterns. The outcrop analogues of the Swabian and Franconian Alb (Fig. 1) represent the reservoir formations of the Molasse Basin and can be used for detailed facies and thermoand petrophysical investigations on a low-cost basis. The integrated analysis of lithology, facies, and corresponding thermo- and petrophysical rock properties as well as the application of relevant reservoir transfer models lead to an improved prognosis of the reservoir properties. An outcrop analogue study of the target formation Malm, which is the most prospective formation for deep geothermal projects in the German Molasse Basin, has to include facies studies following a thermofacies concept (Sass and Götz, 2012).

The investigations are carried out on three different scales: (1) the macroscale, including an outcrop mapping to detect the lithotypes, structural elements and facies patterns in the outcrop; (2) the mesoscale, selecting representative rock samples to determine thermo- and petrophysical properties of different lithotypes in the laboratory; and (3) the microscale, to analyse microstructures, cements, porosities, etc. in thin sections.

\section{Geology}

During the Mesozoic the study area was part of an epicontinental sea north of the Tethys Ocean. To the north the shelf region was confined by an island archipelago of changing dimensions. In the southern, deeper part of this epeiric sea, an extensive siliceous sponge-microbial reef belt developed. With the burial of the Vindelician Ridge a direct connection of the southern German Jurassic Sea with the Tethys Ocean was established (Meyer and Schmidt-Kaler, 1989). During the entire Upper Jurassic a high carbonate production on the shallow shelf resulted in thick limestone series (Selg and Wagenplast, 1990). In the southern, deeper shelf area, a reefal facies a reefal facies developed in the Middle Oxfordian and was part of a facies belt characterized by silicious sponge reefs spanning the northern Tethys shelf (Pieńkowski et al., 2008). Most reefs are microbial crusts; however, coral reefs are also present and become increasingly important towards the end of the Upper Jurassic, mirroring the overall mirroring the overall sea-level fall (Pieńkowski et al., 2008). In addition, clay-rich sediments from the Mid-German High were transported into the shelf area. During times of low carbonate production, the clay content of the sediments increased, which resulted in the sedimentation of marl (Meyer and Schmidt-Kaler, 1990). According to Meyer and SchmidtKaler $(1989,1990)$, the Swabian facies as the central part of the reef belt formed a deeper-water area between the shallower Franconian-southern-Bavarian platform in the east and the Swiss platform in the west. In the southwest, the Swabian shelf facies deepens gradually towards the pelagic facies of 
the Helvetian Basin. The Helvetic facies is characterized by dense, bituminous limestones with, in places, intercalated oolithic layers. This facies describes the transition of the Germanic facies into the Helvetic facies, which is considered as sediments of a deeper shelf area of bedded limestones with very low permeabilities. Karstification is not observed either; thus the northern boundary of the Helvetic facies is considered as the southern boundary of the Malm aquifer of the Molasse Basin (Villinger, 1988).

In general 400-600 $\mathrm{m}$ of carbonate rocks were deposited during the Upper Jurassic, and two major facies can be distinguished (Geyer and Gwinner, 1979; Pawellek and Aigner, 2003):

1. the basin facies, consisting of well-bedded limestones and calcareous marls (mud-/wackestones);

2. the reefal or massive facies when bedding is absent, indistinct or very irregular (rud-/float-/grainstones).

The massive limestones are built by microbial crusts (stromatolites and thrombolites) and siliceous sponges that have been interpreted by various authors as relatively deep and quiet water "reefs", mounds or bioherms (Gwinner, 1976; Leinfelder et al., 1994, 1996; Pawellek and Aigner, 2003). The basin facies may either interfinger with the reefs or onlap onto the reefs (Gwinner, 1976; Pawellek, 2001). In the upper parts of the Upper Jurassic, a coral facies developed locally upon the microbial crust-sponge reefs. The abundance of reef facies differs regularly through time. Reef expansion phases correlate with an increase in the carbonate content within the basin facies, while phases of reef retreat correlate with increasing abundance of marls within the basin facies (Meyer and Schmidt-Kaler, 1989, 1990; Pawellek 2001).

Variations in hydraulic conductivity, particularly within the Upper Jurassic aquifer, are related to lateral changes in lithofacies and degree of karstification (Birner et al., 2012). Thus, it can be assumed that the geothermal potential of the Jurassic aquifer shows a distinct facies-related regional pattern: in the western part of the Molasse Basin (BadenWuerttemberg) the potential is significantly lower than in the eastern part (Bavaria), where the Upper Jurassic aquifer is the major producer of geothermal energy in the area around Munich (Stober, 2013).

\section{Materials and methods}

Reservoir characterization based on thermo- and petrophysical parameters - including permeability, porosity, density, specific heat capacity, thermal diffusivity and thermal conductivity data measured at the same sample - was rarely performed in previous works (e.g. Clauser et al., 2002; Stober et al., 2013). In this study, for direct correlation all parameters are determined at the same sample. More than 350 rock samples from 19 outcrop locations as well as shallow and deep boreholes in Baden-Wuerttemberg and Bavaria (Fig. 1) were collected and analysed. For statistical purposes 3-10 single measurements of different rock properties were conducted on each rock sample; i.e. in total over 1150 measurements for distinct parameters were collected. According to the Dunham (1962) and Embry and Klovan (1971) classification of carbonate rocks the following lithofacies types are detected in the study area: mudstones, wackestones, grain-/packstones and float-/rudstones. The rock classification is also based on previous studies of the Malm formations in southern Germany by Schauer (1998) and Pawellek (2001).

To determine the thermophysical properties of the sampled formations and to generate reproducible results, the samples were dried at $105^{\circ} \mathrm{C}$ to mass constancy and afterwards cooled down to $20^{\circ} \mathrm{C}$ in an exsiccator. A thermal conductivity scanner (optical scanning method after Popov et al., 1985), a gas pressure permeameter (Jaritz, 1999; Hornung and Aigner, 2004) and porosimeter were used. The thermal conductivity scanner is also equipped to determine the thermal diffusivity. The measurement is based on a contact-free temperature measurement with infrared temperature sensors (Bär et al., 2011). The measurement accuracy is about $3 \%$. The determination of the grain and bulk density as well as the porosity was done by measuring the grain and bulk volume of the samples, using a helium pycnometer and a powder pycnometer. The specific heat capacity $c_{\mathrm{p}}$ was measured with a C-80 calorimeter in a temperature range from 20 to $200^{\circ} \mathrm{C}$ for selected samples. Additionally $c_{\mathrm{p}}$ was calculated with the measured thermal conductivity $\lambda$, density $\rho$ and thermal diffusivity $\alpha$ (converted Debye equation):

$c_{\mathrm{p}}=\frac{\lambda}{(\rho \cdot \alpha)}$.

For the determination of the rock permeability a combined column and mini permeameter was used. The method offers either the measurement of the apparent gas permeability which afterwards is converted in permeability or the direct measurement of the intrinsic permeability. The basis for the gas driven permeameter is the Darcy law, which is enhanced by the terms of compressibility and viscosity of gases. To simulate geothermal reservoir conditions, temperature and pressure-dependent parameters must be considered. It is possible to calculate these values for water-saturated rocks under reservoir pressure and temperature conditions for relevant depths (Vosteen and Schellschmidt, 2003; Popov et al., 2003). These parameters can be validated in a ThermoTriaxial-Cell simulating the existing temperature and pressure conditions of the target horizon of a distinct geothermal reservoir and furthermore induces a pore pressure on the rock sample (Pei et al., 2014). The unique design of the ThermoTriaxial-Cell allows experiments with tempered rocks and fluids up to about $170{ }^{\circ} \mathrm{C}$ by applying up to $500 \mathrm{MPa}$ lithostatic pressure and $70 \mathrm{MPa}$ confining pressure. Built of V4A premium steel, the cell can be operated with highly aggressive (corrosive) fluids. Both fluid and rock can be individu- 

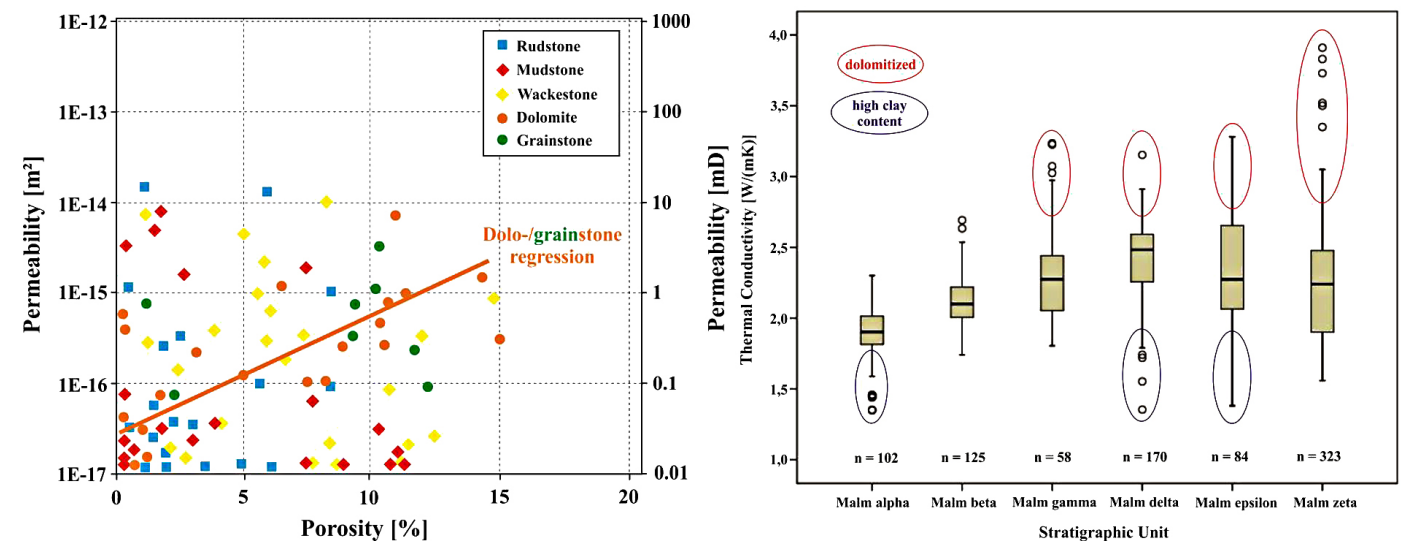

Figure 2. Left: porosity-permeability relationship of different lithotypes (mean values); right: a stratigraphic trend of increasing thermal conductivity is detected from Malm $\alpha$ to Malm $\zeta$ depending on clay and dolomite content (Homuth et al., 2014).

ally tempered, thus allowing a wide range of testing setups to simulate reservoir conditions.

\section{Results}

\subsection{Permeability and porosity}

The matrix permeability of all measured carbonate core samples is quite low except for some grain- and dolostones with higher permeabilities and porosities (Fig. 2). Permeabilities range from $10^{-18}$ to $10^{-13} \mathrm{~m}^{2}(0.001-10 \mathrm{mD})\left(\mathrm{K}\right.$ in $\mathrm{m}^{2}=\mathrm{K}$ in $\left.\mathrm{D} \cdot 9.8692 \times 10^{-13}\right)$. The grain density of the outcrop samples ranges between 2.59 and $2.80 \mathrm{~g} \mathrm{~cm}^{-3}$; the bulk density is between 2.31 and $2.75 \mathrm{~g} \mathrm{~cm}^{-3}$. The porosity calculation based on these values results accordingly in less than $15 \%$. The massive limestones have porosities below $8 \%$, while grainstones and dolomitized zones show increased porosities up to $18 \%$. The permeability measurements state in general very low matrix permeabilities. Only grainstones, reef/coral debris limestones and dolomitized zones show higher permeability ranges up to $10^{-14} \mathrm{~m}^{2}(10 \mathrm{mD})$. A comparison of permeability and porosity indicates that high porosities occur in grain- and dolostones and also cause higher permeability. For all other lithofacies types no correlation between porosity and permeability in regard to interconnected porosity can be inferred (Fig. 2). Diagenetic processes caused dolomitization and de-dolomitization of reef structures and their adjacent transition zones to the basin facies, resulting in an increase of inter-crystalline porosity and therefore increased matrix permeability. On the other hand, if de-dolomitization led to the formation of saccharoidal limestone, permeability decreases due to reduced crystalline porosity. With increasing dolomite content an increase of thermal conductivity is observed due to the higher thermal conductivity of the dolomite crystal structure. The dolomitized areas, related to the geometry of the massive reefal limestone complexes, can span over several stratigraphic units of the Malm, predominantly in the vertical direction (Stober and Villinger, 1997; Schauer, 1998; Koch, 2011; Birner et al., 2012). The dolomitization and dedolomitization processes can have a significant influence on rock permeability, either increasing or reducing the average rock permeability. Including fracture network, dolomitization and karstification, a positive shift of the permeabilityporosity relationship across several magnitudes can be observed. Jodocy and Stober (2011) and Stober et al. (2013) published permeability data obtained from drill core measurements and pump tests, as well as data inferred from geophysical logs and drilling documentation showing hydraulic conductivities of core samples within the same range of values as presented in this study. They also determined an average increase of permeability over 3 magnitudes from core data to pump test data. This shift indicates a high hydrothermal potential of the deep Malm aquifer system in the Molasse Basin. The assumption of a positive permeability correction within the range of 2-3 magnitudes is also based on pump test data and comparisons of matrix and formation productivity from different deep drilling locations in the Molasse Basin (Böhm et al., 2013; Schulz et al., 2012).

\subsection{Thermal conductivity}

Thick-bedded and platy limestones have thermal conductivities of about $2 \mathrm{~W}(\mathrm{~m} \cdot \mathrm{K})^{-1}$, characteristic of limestones. Marly limestones have lower thermal conductivities than thick-bedded and platy limestones, showing the same range of permeabilities as the thick-bedded limestones. It seems that the higher clay content of the marly limestones decreases the thermal conductivity by insulating the heat conduction and at the same time showing only minor effects on permeability, which shows the same range for mud- and wackestones. The thermal conductivities of different reefal limestones have values of $1.8-3.9 \mathrm{~W}(\mathrm{~m} \cdot \mathrm{K})^{-1}$, related to the higher content of secondarily silicified reef bodies and due to dolomitization of reefal structures. The layers with increased 
silica content are identified as layers with silicified sponge build-ups (Leinfelder et al., 1994, 1996). The dolomitized carbonates show the highest values of thermal conductivity of all investigated carbonates in this study. For some stratigraphic units trends are detectable (Fig. 2): increasing thermal conductivity from Malm $\alpha$ to Malm $\zeta$, due to decreasing clay content and increasing dolomitization (the maximum of the dolomitization is also found within the Malm $\delta$ by Schauer $(1996,1998))$. A peak of thermal conductivity observed in the Malm $\delta$ also correlates with an increased silica content of silicified sponge build-ups.

\subsection{Comparison of results from shallow and deep drill cores and cuttings}

The presented data of outcrop analogue studies are based on rock measurements on oven-dried cores, which are conducted under laboratory conditions with atmospheric pressure and room temperature of $20^{\circ} \mathrm{C}$. This approach guarantees a very good reproducibility of the results but also requires a correction of the measured data for reservoir conditions. It is assumed that the reservoir is completely saturated. For the following analyses, the temperature and pressure conditions of a $5000 \mathrm{~m}$ deep (= lithostatic pressure: $130 \mathrm{MPa}$ ) and $150^{\circ} \mathrm{C}$ hot reservoir, which are realistic values for the Molasse Basin, are estimated.

The thermal conductivity of water-saturated rocks can be calculated following the model of Lichtenecker and numerous other authors (Clauser and Huenges, 1995; Popov et al., 2003; Hartmann et al., 2005). Temperature dependency models of thermophysical properties of different rock types can be found in Somerton (1992), Vosteen and Schellschmidt (2003) and Abdulagatova et al. (2009). In general, the thermal conductivity decreases with increasing temperature and increases with increasing pressure (Clauser and Huenges, 1995). The fundamental effects are the reduction of pore space and the increasing temperature with increasing depth (Clauser et al., 2002). Both parameters control the fluid and matrix conditions, although in terms of tight carbonates the temperature-dependent porosity reduction is the dominant factor. Also for tight carbonates the lithostatic pressure has only a minor influence on the porosity-permeability relationship (Bjørkum et al., 1998).

Table 1 shows the range of measured values and calculated transfer values of different thermophysical rock properties for different facies types of the Malm carbonates. For comparison also the calculated reservoir rock properties with respect to the distinct reservoir conditions $\left(150^{\circ} \mathrm{C}\right.$, $5000 \mathrm{~m}$ depth) and accordingly applied correction functions are listed. In terms of matrix porosity and permeability it is concluded that the low rock porosity measured on the outcrop samples will not change significantly with increasing depth in regards to effective hydraulic conductivity. In terms of the mean reservoir porosity the temperature of the carbonate systems is the dominant factor with regard to the thermal

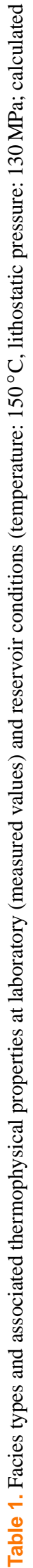

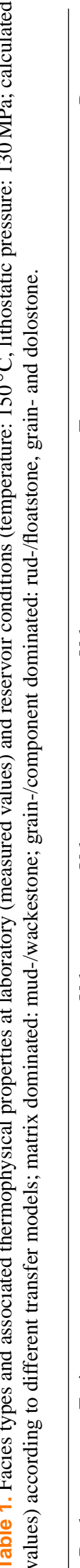




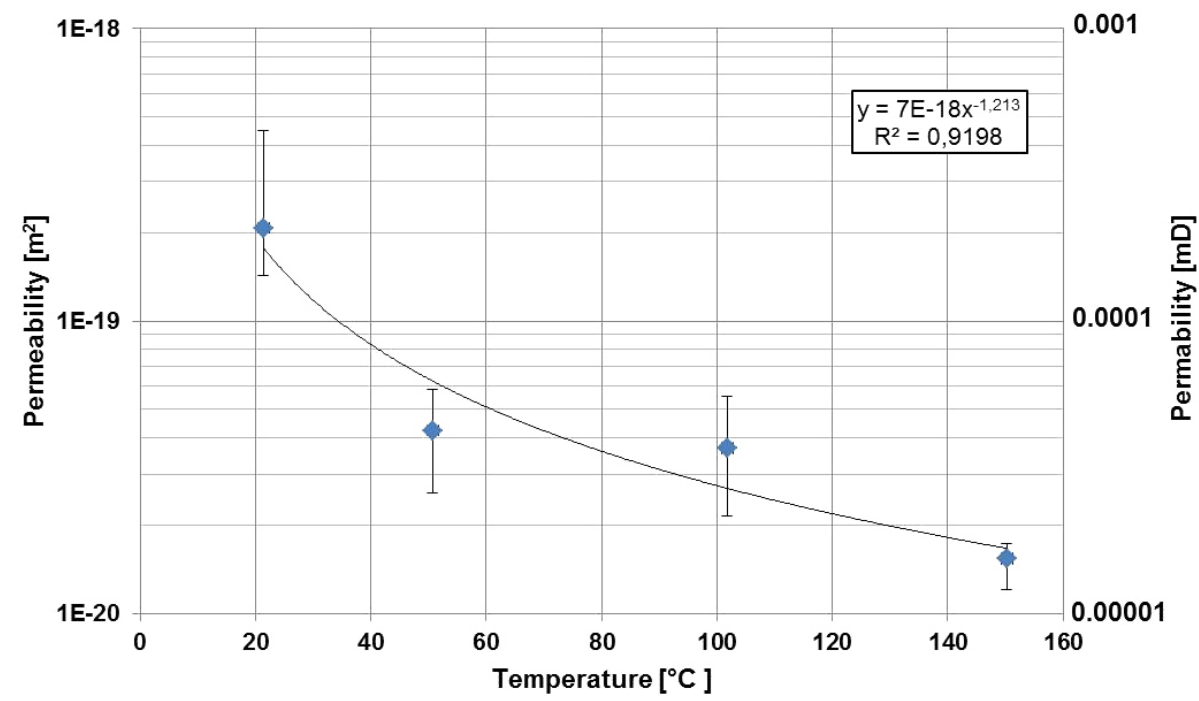

Figure 3. Decrease of permeability of four different lithotype outcrop samples under reservoir pressure and increasing temperature regime starting at $20^{\circ} \mathrm{C}$ up to $150^{\circ} \mathrm{C}$ (reservoir temperature). Points show the average permeability; bars indicate the value range of the four tested samples.

expansion and carbonate chemistry, and not the depth of the reservoir (Bjørkum and Nadeau, 1998). A comparison with other carbonate reservoir data (Ehrenberg and Nadeau, 2005) and a thermo-triaxial test series (Fig. 3) on outcrop samples confirms this approach.

The thermo-triaxial apparatus of the TU Darmstadt Geothermal Laboratory has been developed to facilitate research on petrophysical properties of rock samples under simulated geothermal reservoir conditions. The test device consists of control systems for vertical stress and horizontal confining pressure, a pair of independent pore pressure controllers for applying different upstream and downstream pore pressures at the base and top of rock specimens, an external heater and a data logging system. The permeability of rocks is measured using steady-state and transient flow methods (Pei et al., 2014). Different lithotype samples tested with the thermo-triaxial cell showed initial permeabilities, measured under laboratory conditions with an air-driven permeameter, of about $3.5 \times 10^{-16} \mathrm{~m}^{2}$. After complete water saturation of the samples an average decrease of permeability of about 2 magnitudes is observed $\left(4.3 \times 10^{-18} \mathrm{~m}^{2}\right)$. When applying reservoir pressure (vertical stress: $130 \mathrm{MPa}=5000 \mathrm{~m}$ depth, confining stress: $30 \mathrm{MPa}$ (due to experimental cell setup); pore pressure: $1 \mathrm{MPa})$ and temperature $\left(150^{\circ} \mathrm{C}\right)$, a total shift of permeability of about 2-3 magnitudes compared to the samples origin permeability measured under laboratory conditions is measured (Fig. 3). Based on these experiments the following matrix permeability-temperature relationship for the Malm carbonates is inferred:

$K_{\text {temp }}=K_{(0, \text { sat })} \cdot T^{(-1,213)}$, where $K_{\text {temp }}$ is the temperature-dependent permeability in $\mathrm{m}^{2}, K_{(0, \text { sat })}$ is the water-saturated permeability in $\mathrm{m}^{2}$ at $20^{\circ} \mathrm{C}$ and $T$ is temperature in ${ }^{\circ} \mathrm{C}$.

The measurements of shallow (Solnhofen-Maxberg, Oberdolling) and deep drill cores from a $1600 \mathrm{~m}$ deep research core drilling (Moosburg SC4) and a $4850 \mathrm{~m}$ deep production well (GEN-1, cuttings only) confirm the above-stated assumptions and correction functions applied on the outcrop values. In terms of permeability a significant change is only inferable for greater depth and higher temperature. The permeability values obtained from cores in depth of $1600 \mathrm{~m}$ show typical values of permeability comparable to the value range of outcrop samples. The thermal conductivity shows only minor to negligible differences compared with the outcrop results, except for the depth range of 230, 1300-1500, 4400 and $4700-4850 \mathrm{~m}$ where dolomitized zones of massive facies in the Malm $\zeta 1$ and $\zeta 2$ are encountered. The dolomitization process results here in a significant increase (up to $2.5 \mathrm{~W}(\mathrm{~m} \cdot \mathrm{K})^{-1}$ ) of thermal conductivity. The temperature influence at greater depth $(4850 \mathrm{~m})$ shows a decrease of thermal conductivity and an increase of specific heat capacity (Fig. 4).

Thermophysical correlations between different reservoir properties are controlled by lithofacies. Based on the Debye equation (Eq. 1) and the analyses of measurements (Fig. 4), it can be inferred that the thermophysical properties for tight carbonate rocks are density-controlled. Density itself is strongly dependent on the lithofacies of the carbonate rock; i.e. the massive and basin facies have direct influence on the formations' hydraulic conductivity. In the transition zone of basin to massive (reef) facies, sub-vertical fractures caused by differential compaction between massive facies and ad- 


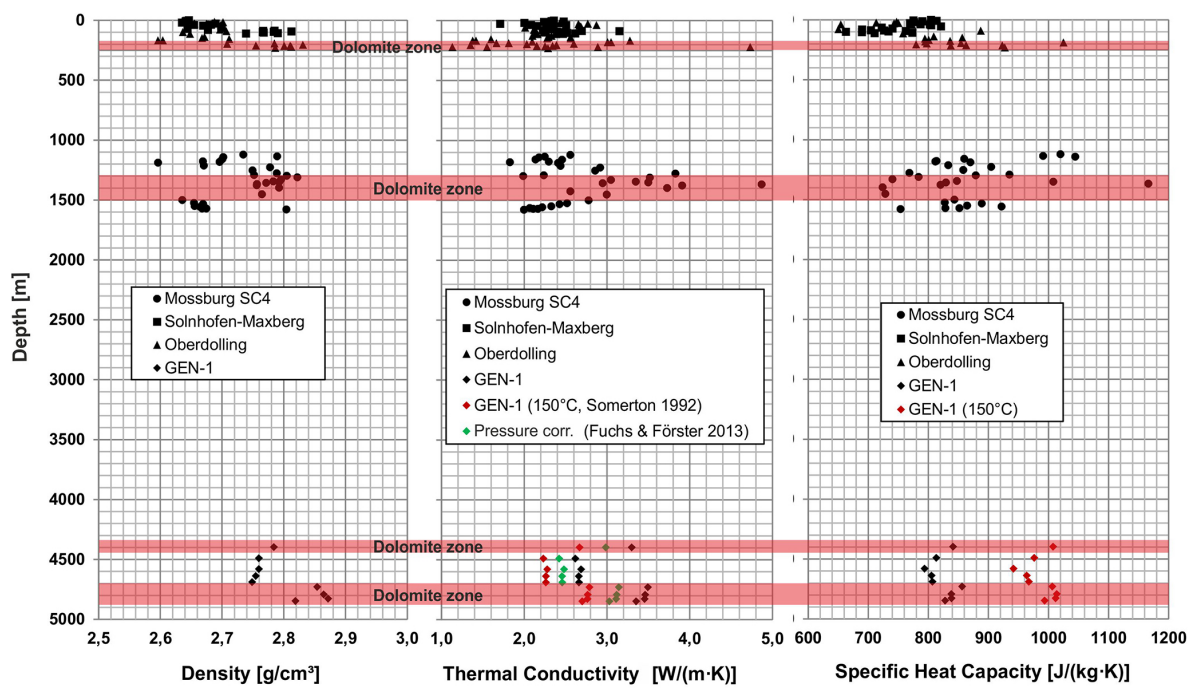

Figure 4. Comparison of density, thermal conductivity and specific heat capacity of drilling locations in the outcrop analogue area (Solnhofen-Maxberg) and the Molasse Basin (Oberdolling, Moosburg SC4 and Geretsried GEN-1).

jacent basin facies can also be observed in the studied outcrops. Due to the increased fracture density in this zone, the karstification process is favoured, which results in dissolution of carbonate. The increased hydraulic conductivity results either in the disintegration into dolomite sand or in the process of de-dolomitization (re-calcification). In this context it is important to consider that dolomitized zones, due to their primary facies and genesis, even on a small scale are laterally variable and developed across fractures and porous zones into adjacent facies (Koch, 2011). Therefore, the identification and location of such zones is of special interest for the geothermal reservoir prognosis in terms of hydraulically prospective reservoir formations.

The thermal conductivity, porosity and permeability values presented herein are in good accordance with results of recent studies on a limited number of rock samples from the Molasse Basin (Koch et al., 2007, 2009; Böhm et al. 2013).

\section{Conclusions}

The studied rocks of the Upper Jurassic are not a homogenous formation of limestones. Even on a small scale, different facies types and their interfingering - which can be differentiated in geometry, structure, fabric and composition can be identified. These differences affect the thermophysical properties of the rocks and show facies-related trends. The hydraulic parameters vary on the order of 4 magnitudes within a stratigraphic unit or facies zone, but in general they show a range of poor to very poor matrix hydraulic conductivity (cf. Stober et al., 2013). From outcrop studies it can be inferred that hydraulic active pathways are bound to fracture networks, faults and adjacent karstification and/or dolomitized zones. The secondary reservoir permeability is strongly related to the tectonic setting and facies-controlled diagenesis. Additionally, reservoir permeability depends on the hydrochemical conditions of the carbonate reservoir to maintain open flow paths. Based on the investigation of the matrix parameters, the sustainable heat transport into the utilized geothermal reservoir can be assessed. Thus, the long-term capacities for different utilization scenarios can be calculated more precisely. With the help of 3-D seismic surveys the investigation of lateral extension and related facies heterogeneity will give valuable information on the transmissibility of different target horizons/facies. The thermofacies characterization and prediction of geothermal reservoir parameters enables the identification of prospective exploration areas. However, the structural hydraulic conductivity of fault zones has to be addressed as a first step in exploration, followed by lithofacies studies to ensure a successful exploration strategy for the Upper Jurassic aquifer exploitation.

The data from the Upper Jurassic limestones of southern Germany show that the prognosis of reservoir properties applying facies models can be implemented as an additional exploration tool. The determination of geothermal reservoir properties serves in general to distinguish between petrothermal and hydrothermal systems (Sass and Götz, 2012) and can also be used to optimize the drilling and stimulation design. Outcrop analogue studies are an effective tool to create a database in an early project phase. Ultimately, the assessment of production capacities of geothermal reservoirs becomes more reliable; applying reservoir transfer models to the database predicted reservoir properties at greater depths and higher temperatures. Furthermore, these studies provide a sufficient database to determine thermophysical reservoir characteristics of the rock matrix which can be used for optimized temperature distribution modelling of geothermal reservoir formations. Facies concepts are applied as an explo- 
ration tool producing conservative results. Adding information on secondary porosities, karstification, dolomitization and stress field into a reservoir model will enable estimating realistic reservoir capacities. The key to a reliable reservoir prognosis, reservoir stimulation and sustainable reservoir utilization for the Malm in the Molasse Basin is to integrate statistically tested databases of tectonic, hydraulic and thermofacies features into 3-D reservoir models.

Acknowledgements. The authors thank the Bayerisches Landesamt für Umwelt (LfU) for the permission to sample shallow and deep research drillings. We also thank the ENEX Power Germany $\mathrm{GmbH}$ for support and access to cutting material from the drill site GEN-1 in Geretsried. Furthermore, we acknowledge the contribution of numerous students who performed measurements of geothermal rock parameters in the framework of their theses at the Institute of Applied Geosciences, Technische Universität Darmstadt. The constructive comments of Ingrid Stober and an anonymous reviewer greatly improved the manuscript.

Edited by: I. S. Moeck

Reviewed by: I. Stober and one anonymous referee

\section{References}

Abdulagatova, Z., Abdulagatov, I. M., and Emirov, V. N.: Effect of temperature and pressure on the thermal conductivity of sandstone, Int. J. Rock Mech. Min., 46, 1055-1071, 2009.

Bär, K., Arndt, D., Fritsche, J.-G., Götz, A. E., Kracht, M., Hoppe, A., and Sass, I.: 3-D-Modellierung der tiefengeothermischen Potenziale von Hessen: Eingangsdaten und Potenzialausweisung, Z. Dt. Ges. Geowiss., 162, 371-388, 2011.

Birner, J., Fritzer, T., Jodocy, M., Savvatis, A., Schneider, M., and Stober, I.: Hydraulische Eigenschaften des Malmaquifers im Süddeutschen Molassebecken und ihre Bedeutung für die geothermische Erschließung, Z. Geol. Wiss., 40, 133-156, 2012.

Bjørkum, P. A. and Nadeau, P. H.: Temperature controlled porosity/permeability reduction, fluid migration, and petroleum exploration in sedimentary basins, Australian Pet. Prod. Expl. Assoc. J., 38, 453-464, 1998.

Böhm, F., Savvatis, A., Steiner, U., Schneider, M., and Koch, R.: Lithofazielle Reservoircharakterisierung zur geothermischen Nutzung des Malm im Großraum München, Grundwasser, 18, 3-13, 2013.

Chilingarian, G. V., Mazzullo, S. J., and Rieke, H. H.: Carbonate Reservoir Characterization: A Geologic-Engineering Analysis, Elsevier Sci. Publs. B. V., Amsterdam, the Netherlands, 639 pp., 1992.

Clauser, C. (Ed.): Numerical Simulation of Reactive Flow in Hot Aquifers - SHEMAT and Processing SHEMAT, Springer-Verlag, Berlin Heidelberg, Germany, doi:10.1007/978-3-642-55684-5, 2003.

Clauser, C. and Huenges, E.: Thermal Conductivity of Rocks and Minerals, Rock Physics and Phase Relations, A Handbook of Physical Constants, AGU Reference Shelf, 3, 105-126, 1995.

Clauser, C., Deetjen, H., Höhne, F., Rühaak, W., Hartmann, A., Schellschmidt, R., Rath, V., and Zschocke, A.: Erkennen und
Quantifizieren von Strömung: Eine geothermische Rasteranalyse zur Klassifizierung des tiefen Untergrundes in Deutschland hinsichtlich seiner Eignung zur Endlagerung radioaktiver Stoffe, Endbericht zum Auftrag 9X0009-8390-0 des Bundesamtes für Strahlenschutz (BfS), Applied Geophysics and Geothermal Energy E.ON Energy Research Center, RWTH Aachen, Germany, 159 pp., 2002.

Dunham, R. J.: Classification of carbonate rocks according to depositional texture, in: Classification of carbonate rocks, edited by: Ham, W. E., AAPG Memoir, 1, 108-171, 1962.

Ehrenberg, S. N. and Nadeau, P. H.: Sandstone versus carbonate petroleum reservoirs: a global perspective on porosity-depth and porosity-permeability relationships, AAPG Bulletin, 89, 435445, 2005.

Embry, A. F. and Klovan, J. E.: A Late Devonian reef tract on Northeastern Banks Island, NWT: Canadian Petroleum Geology Bulletin, 19, 730-781, 1971.

Fuchs, S. and Förster, A.: Well-log based prediction of thermal conductivity of sedimentary successions: a case study from the North German Basin, Geophys. J. Int., 196, 291-311 doi:10.1093/gji/ggt382, 2013.

Geyer, O. F. and Gwinner, M. P.: Die Schwäbische Alb und ihr Vorland, Slg. Geol. Führer, 67, 271 pp., 1979.

Gwinner, M. P.: Origin of the Upper Jurassic of the Swabian Alb, Contrib. Sedimentol., 5, 1-75, 1976.

Hartmann, A., Rath, V., and Clauser, C.: Thermal conductivity from core and well log data, Int. J. Rock Mech. Min., 42, 1042-1055, 2005.

Homuth, S., Götz, A. E., and Sass, I.: Facies relation and depth dependency of thermo- and petrophysical rock parameters of the Upper Jurassic geothermal carbonate reservoirs of the Molasse Basin, Z. Dt. Ges. Geowiss., 165, 469-486, 2014.

Hornung, J. and Aigner, T.: Sedimentäre Architektur und PoropermAnalyse fluviatiler Sandsteine: Fallbeispiel Coburger Sandstein, Franken, Hallesches Jahrb. Geowiss., Reihe B, 18, 121-138, 2004.

Jaritz, R.: Quantifizierung der Heterogenität einer Sandsteinmatrix am Beispiel des Stubensandstein (Mittlerer Keuper, Württemberg), Tübinger Geol. Abhandlungen, Reihe C, 48, 1-104, 1999.

Jodocy, M. and Stober, I.: Porosities and Permeabilities in the Upper Rhine Graben and in the SW Molasse Basin (Germany), Erdöl Erdgas Kohle, 127, 20-27, 2011.

Koch, R.: Dolomit und Dolomit-Zerfall im Malm Süddeutschlands - Verbreitung, Bildungsmodelle, Dolomit-Karst, Laichinger Höhlenfreund, 46, 75-92, 2011.

Koch, A., Hartmann, A., Jorand, R., Mottaghy, D., Pechnig, R., Rath, V., Wolf, A., and Clauser, C.: Erstellung statistisch abgesicherter thermischer und hydraulischer Gesteinseigenschaften für den flachen und tiefen Untergrund in Deutschland (Phase 1 - Westliche Molasse und nördlich angrenzendes Süddeutsches Schichtstufenland), Schlussbericht zum BMU-Projekt FKZ 0329985, RWTH Aachen, Germany, 220 pp., 2007.

Koch, A., Jorand, R., Arnold, J., Pechnig, R., Mottaghy, D., Vogt, C., and Clauser, C.: Erstellung statistisch abgesicherter thermischer und hydraulischer Gesteinseigenschaften für den flachen und tiefen Untergrund in Deutschland (Phase 2 - Westliches Nordrhein-Westfalen und bayerisches Molassebecken), Abschlussbericht zum BMU-Projekt FKZ 0329985, Aachen (RWTH), Germany, 174 pp., 2009. 
Leinfelder, R. R., Krautter, M., Laternser, R., Nose, M., Schmid, D. U., Schweigert, G., Werner, W., Keupp, H., Brugger, H., Hermmann, R., Rehfeld-Kiefer, U., Schroeder, J. H., Reinhold, C., Koch, R., Zeiss, A., Schweizer, V., Christmann, H., Menges, G., and Luterbacher, H.: The origin of Jurassic reefs: current research developments and results, Facies, 31, 1-56, 1994.

Leinfelder, R. R., Werner, W., Nose, M., Schmid, D. U., Krautter, M., Laternser, R., Takacs, M., and Hartmann, D.: Paleoecology, growth parameters and dynamics of coral, sponge and microbolite reefs from the late Jurassic, Gött. Arb. Geol. Paläontol., 2, 227-248, 1996.

Meyer, R. K. F. and Schmidt-Kaler, H.: Paläogeographischer Atlas des süddeutschen Oberjura (Malm), Geol. Jb., A/115, 3-77, 1989.

Meyer, R. K. F. and Schmidt-Kaler, H.: Paläogeographie und Schwammriffentwicklung des süddeutschen Malm - ein Überblick, Facies, 23, 175-184, 1990.

Moeck, I. and Beardsmore, G.: A new "geothermal play type" catalog: Streamlining exploration decision making, Proceedings, Thirty-Ninth Workshop on Geothermal Reservoir Engineering Stanford University, Stanford, California, 2014.

Pawellek, T.: Fazies-, Sequenz-, und Gamma-Ray-Analyse im höheren Malm der Schwäbischen Alb (SW-Deutschland) mit Bemerkungen zur Rohstoffgeologie (hochreine Kalke), Tübinger Geol. Arb., Reihe A, 61, 1-246, 2001.

Pawellek, T. and Aigner, T.: Apparently homogenous "reef"limestones built by high-frequency cycles Upper Jurassic, SWGermany, Sediment. Geol., 160, 259-284, 2003.

Pei, L., Rühaak, W., Stegner, J., Bär, K., Homuth, S., Mielke, P., and Sass, I.: Thermo-Triax: An Apparatus for Testing Petrophysical Properties of Rocks Under Simulated Geothermal Reservoir Conditions, Geotech. Testing J., 38, 1-20, 2014.

Pieńkowski, G., Schudack, M. E., Bosák, P., Enay, R., FeldmanOlszewska, A., Golonka, J., Gutowski, J., Herngreen, G. F. W., Jordan, P., Krobicki, M., Lathuilière, B., Leinfelder, R. R., Michalík, J., Mönnig, E., Noe-Nygaard, N., Pálfy, J., Pint, A., Rasser, M. W., Reisdorf, A. G., Schmid, D. U., Schweigert, G., Surlyk, F., Wetzel, A., and Wong, T. E.: Jurassic, in: The Geology of Central Europe, edited by: McCann, T., The Geological Society, London, UK, 2: Mesozoic and Cenozoic: 823-922, 2008.

Popov, Y. A., Berezin, V. V., Semenov, V. G., and Korostelev, V. M.: Complex detailed investigations of the thermal properties of rocks on the basis of a moving point source, Phys. Solid Earth, 21, 64-70, 1985.

Popov, Y. A., Tertychnyi, V., Romushkevich, R., Korobkov, D., and Pohl, J.: Interrelations between thermal conductivity and other physical properties of rocks: experimental data, Pure App. Geophys., 160, 1137-1161, 2003.
Sass, I. and Götz, A. E.: Geothermal reservoir characterization: a thermofacies concept, Terra Nova, 24, 142-147, 2012.

Sass, J. H., Lachenbruch, A. H., Munroe, R. J., Greene, G. W., and Moses Jr., T. H.,: Heat Flow in the Western United States, J. Geophys. Res., 76, 6376-6413, 1971.

Schauer, M.: Untersuchungen an Dolomitsteinen und zuckerkörnigen Kalksteinen auf der Mittleren Schwäbischen Alb, Laichinger Höhlenfreund, 31, 5-18, 1996.

Schauer, M.: Dynamische Stratigraphie, Diagenese und Rohstoffpotenzial des Oberjura (Kimmeridge 1-5 der mittleren Schwäbischen Alb, Tübinger geowissenschaftliche Arbeiten, Tübingen Universität Tübingen, Germany, Reihe A, 36, 1998.

Schulz, R. (Ed.), Thomas, R., Dussel, M., Lüschen, E., Wenderoth, F., Fritzer, T., Birner, J., Schneider, M., Wolfgramm, M., Bartels, J., Hiber, B., Megies, T., and Wassermann, J.: Geothermische Charakterisierung von karstig-klüftigen Aquiferen im Großraum München, Final report, Hannover (LIAG), Germany, Förderkennzeichen 0325013A, 2012.

Selg, M. and Wagenplast, P.: Beckenarchitektur im süddeutschen Weißen Jura und die Bildung der Schwammriffe, Jh. Geol. Landesamt Baden-Württemberg, 32, 171-206, 1990.

Somerton, W. H.: Thermal properties and temperature-related behavior of rock-fluid systems, Dev. Petr. Sci., 37, 257 pp., 1992.

Stober, I.: Die thermalen Karbonat-Aquifere Oberjura und Oberer Muschelkalk im Südwestdeutschen Alpenvorland, Grundwasser, 18, 259-269, 2013.

Stober, I. and Villinger, E.: Hydraulisches Potential und Durchlässigkeit des höheren Oberjuras und des Oberen Muschelkalks unter dem Baden-Württembergischen Molassebecken, Jh. geol. L.-Amt Baden-Württemberg, 37, 7-24, 1997.

Stober, I., Jodocy, M., and Hintersberger, B.: Gegenüberstellung von Durchlässigkeiten aus verschiedenen Verfahren im tief liegenden Oberjura des südwestdeutschen Molassebeckens, Z. Dt. Ges. Geowiss (German J. Geosci.), 164, 663-679, 2013.

Villinger, E.: Hydrogeologische Ergebnisse, in: Ergebnisse der Hydrogeothermiebohrungen in Baden-Württemberg, edited by: Bertleff, B. W., Joachim, H., Koziorowski, G., Leiber, J., Ohmert, W., Prestel, R., Stober, J., Strayle, G., Villinger, E., and Werner, W., Jh. Geol. Landesamtes Baden-Württemberg, 30, 27-116, 1988.

Vosteen, H.-D. and Schellschmidt, R.: Influence of temperature on thermal conductivity, thermal capacity and thermal diffusivity for different types of rock, Phys. Chem. Earth, 28, 499-509, 2003.

Zoth, G. and Hänel, R.: Thermal conductivity, in: Handbook of Terrestrial Heat Flow Density Determination, edited by: Hänel, R., Rybach, L., and Stegena, L., Kluwer Academic Publishers, 449453, 1988. 